\title{
PENINGKATAN KEMAMPUAN TEKNIK MENGAJAR BAHASA INDONESIA \\ PADA MAHASISWA IKIP PGRI JEMBER MELALUI METODE DISKUSI \\ KELOMPOK KECIL DAN MEDIA GAMBAR
}

\section{Nurhafit Kurniawan, S.Pd, M.Pd \\ IKIP PGRI JEMBER \\ nurhafit@yahoo.com}

\begin{abstract}
ABSTRAK
Sebagian besar Mahasiswa Prodi PG PAUD IKIP PGRI JEMBER, masih belum memiliki kemampuan membuat kalimat sapaan, ucapan selamat, ucapan terima kasih, dan permintaan maaf. Penelitian ini bertujuan untuk menjelaskan proses peningkatan kemampuan penggunaan bahasa Indonesia dalam membuat kalimat menyapa dan meningkatkan kemampuan penggunaan bahasa Indonesia dalam membuat kalimat. Penelitian ini didesain sebagai penelitian tindakan dengan dua siklus. Analisis data menggunakan analisis deskriptif baik dengan pendekatan kualitatif maupun kuantitatif (persentase). Temuan penelitian menunjukkan bahwa proses pembelajaran dengan menggunakan meode diskusi kelompok kecil dan media gambar telah berjalan cukup efektif. Demikian halnya kemampuan Mahasiswa dalam membuat kalimat juga semakin meningkat, baik secara individu dan secara klasikal. Simpulan penelitin meunujukkan bahwa metode diskusi kelompok kecil dan media gambar dapat diterapkan oleh mahasiswa agar dapat meningkatkan kemampuan siswa dalam membuat kalimat sapaan, ucapan selamat, ucapan terima kasih, dan permintaan maaf.
\end{abstract}

Kata Kunci: Membuat kalimat, diskusi kelompok kecil, media gambar, hasil belajar 


\begin{abstract}
Most of the students of the PG PAUD PGRI JEMBER Study Program, still do not have the ability to make greeting sentences, congratulations, thanks, and apologies. This study aims to explain the process of increasing the ability to use Indonesian in making sentences greeting and increasing the ability to use Indonesian in making sentences. This study was designed as an action research with two cycles. Data analysis used descriptive analysis with both qualitative and quantitative approaches (percentages). The research findings show that the learning process by using small group discussion methods and image media has run quite effectively. Likewise, the ability of students to make sentences also increases, both individually and classically. The conclusion of the research shows that the method of small group discussion and image media can be applied by students to be able to improve students' abilities in making greeting sentences, congratulations, thanks, and apologies.
\end{abstract}

Keywords: Making sentences, small group discussions, picture media, learning outcomes

\section{PENDAHULUAN}

\begin{tabular}{llr}
\multicolumn{2}{c}{ Mahasiswa IKIP } & PGR \\
JEMBER masih kesulitan & dalam \\
mengajarkan pelajaran & bahasa \\
Indonesia utamanya dalam
\end{tabular}

menuliskan suatu kalimat. Padahal KD Bahasa Indonesia menuntut agar anak bisa membuat kalimat tentang sapaan, menyampaikan ucapan selamat, terima kasih, dan permohonan maaf sesuai dengan konteksnya. Apabila para Mahasiswa mampu mengajarkan berbagai jenis kalimat, maka akan mempermudah mereka untuk melakukan proses komunikasi baik secara langsung maupun melalui tulisan. Namun demikian kondisi anak-anak di kelas belum menunjukkan adanya kemampuan dalam menyusun kealimat, utamanya kalimat sapaan, menyampaikan ucapan selamat, terima kasih, dan permohonan maaf. Masalah ini adalah mendesak untuk diselesaikan, mengingat bahwa kalimat-kalimat tersebut akan banyak digunakan dalam kehidupan ke seharian anak

Kekurangan mahasiswa dalam memberikan beberapa contoh kalimat diakui oleh sebagian besar Mahasiswa. Sehingga berdampak pada siswa/murid disekolah yaitu bingung untuk membedakan kalimat menyapa dan ucapan terima kasih. Demikian juga masih banyak anak yang kesulitan untuk membuat kalimat permohonan maaf. Kesemua kesulitan tersebut teridentifikasi saat proses pemberian tugas di kelas, maupun dari hasil pekerjaan yang mereka kumpulkan.Kondisi seperti ini bisa jadi disebabkan oleh berbagai hal, bisa dari faktor cara 
mengajar guru, kemampuan Mahasiswa, maupun metode dan media pembelajaran yang diterapkan oleh guru kurang sesuai .

Sebagai akibat dari kelemahan di atas, anak-anak menjadi kurang tertarik untuk mempelajari dan mengikuti pelajaran bahasa Indonesia. Bila hal ini dibiarkan secara terus-menerus, akan berdampak pada hasil belajar anak pada mata pelajaran bahasa Indonesia yang menurun.

\section{METODE PENELITIAN}

Berdasar dari realita di atas maka permasalahan tersebut harus segera diatasi. Adapun rencana tindakan yang akan dilakukan adalah dengan menerapkan metode diskusi kelompok kecil dan media gambar untuk meningkatkan keterampilan anak dalam Membuat Kalimat Sapaan, Ucapan Terima Kasih dan Permintaan Maaf dengan Menggunakan Metode Diskusi Kelompok Kecil dan Media Gambar. Sebab dengan menggunakan metode diskusi, proses interaksi dan saling mengisi di antara para Mahasiswa yang sudah mampu dan yang belum bisa mempermudah mereka dalam memahami materi. Dengan menggunakan media gambar, maka harapannya adalah anak/siswa akan lenbih mudah dalam membuat kalimat, karena contoh yang ada pada gambar, lebih mudah difahami, dan lebih konkrit. Ini sesuai dengan teori Piaget, bahwa anak pada usia dini masih berfikir konkrit. Sebagai subjek penelitian adalah seluruh Mahasiswa semester V Prodi PG PAUD IKIP PGRI Jember yang berjumlah sekitar 31 Mahasiswa. Alasan pokok penentuan Mahasiswa semester $\mathrm{V}$ untuk dijadikan sebagai subjek penelitian, karena secara umum para Mahasiswa masih kesulitan untuk memberikan pelajaran pada siswa prihal kalimat tentang sapaan, ucapan terima kasih, dan permintaan maaf, padahal mereka sudah akan segera mengikuti praktik pengalaman lapangan (PPL).

Penelitian ini dilaksanakan selama dua bulan. Yaitu mulai awal bulan Oktober hingga akhir November 2018. Aktivias yang dilakukan selama dua bulan tersebut dimulai dari proses identifikasi masalah, hingga terpilihnya judul 
PTK hingga pelaporan hasil penelitian. Penelitian ini dirancang sebagai Penelitian Tindakan Kelas (PTK). Untuk itu, desain penelitian ini lebih bersifat deskriptif. Adapun model PTK yang digunakan adalah modifikasi dari model Kemmis dan McTaggart, yang direncanakan selama 2 siklus. Penelitian ini berupa

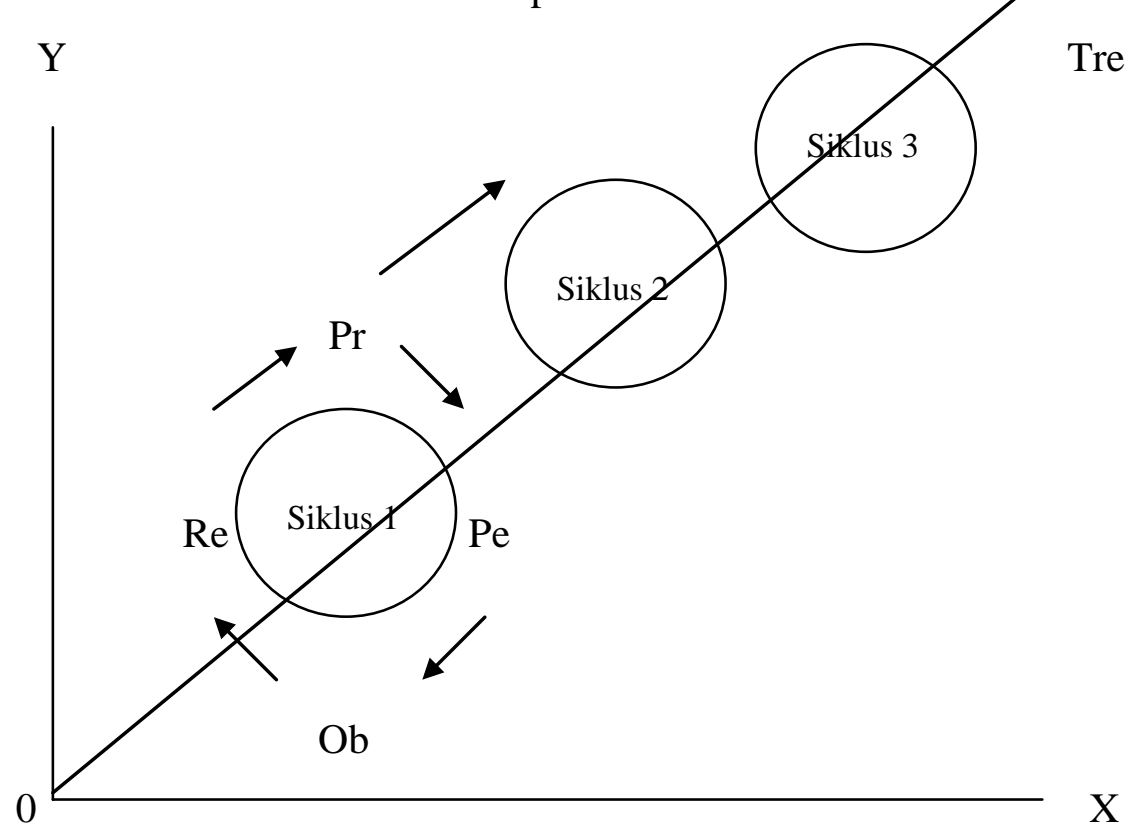

Model Penelitian Tindakan Kelas

Note:

$$
\begin{array}{ll}
\mathrm{Pr} & \text { : Perencanaan } \\
\mathrm{Pe} & \text { : Pelaksanaan }
\end{array}
$$

Prosedur penelitian ini menurut Kasbollah (1998) meliputi beberapa langkah yang harus dilakukan: a) tahap perencanaan atau persiapan; b) tahap pelaksanaan; c) tahap observasi; d) dan tahap siklus-siklus kegiatan yang semakin lama semakin efektif. Setiap siklus kegiatan terdiri dari tahap perencanaan, tahap pelaksanaan, tahap observasi dan tahap refleksi. Secara grafis menurut Purnomo (1999) siklus-siklus tersebut dapat dilihat pada gambar di bawah ini. 
Ada dua teknik analisis data yang akan digunakan dalam peneltian tindakan kelas ini (PTK). Untuk menggambarkan keadaan subjek penelitian, digunakan teknik diskriptif dengan pendekatan kualitatif, yaitu dengan menggambarkan kondisi Mahasiswa baik sebelum penelitian maupun pada saat penelitian di kelas, atau saat akhir proses pembelajaran. Sedangkan untuk mengetahui seberapa efektif penelitian ini apakah telah menunjukkan perkembangan kemampuan anak dalam membuat kalimat telah berhasil atau belum, maka digunakan analisis kuantitatif (persentase).

Hasil dari analisis data tersebut akan dibandingkan dengan indikator ketercapai (kreteria). Untuk kemampuan Mahasiswa dalam membuat kalimat hasil penilainnnya dilakukan dengan cara membandingkan antara kreteria tatau target yang ditetapkan yaitu dengan nilai > 70 (sesuai KKM). Sementara diskusi kelompok kecil ditargertkan bisa berjalan sesuai sintaks (prosedur) metode diskusi kelompok kecil dengan kategori sesuai.
Sedangkan untuk media gambar diukur dari kualitas gambar dengan kategori baik dan menarik. Apabila semua target terpenuhi maka siklus lanjutan tidak perlu dilanjutkan, karena sudah dianggap kegiatan pembelajarannya berhasil.

\section{HASIL DAN PEMBAHASAN}

Pada bab ini akan dideskripsikan tentang hasil dan pembahasan tentang: 1) bagaimanakah proses penerapan diskusi kelompok kecil dan media gambar dalam pembelajaran kemampuan menulis berbagai kalimat; dan 2) bagaimanakah kemampuan mahasiswa dalam mengajarkan berbagai macam kalimat (kalimat sapaan, ucapan selamat, ucapan terima kasih, dan permintaan maaf) setelah ditetapkannya metode diskusi kelompok kecil dan media gambar pada mahasiswa semester V Prodi PG PAUD IKIP PGRI Jember.

Pada pembahasan ini dideskripsikan dua hal yaitu, tentang proses pembelajaran dan perkembangan hasil pembelajaran 
mulai dari siklus 1 dan siklus 2. Pada akhir bagian ini juga dideskripsikan perkembangan hasil belajar mulai prasiklus hingga siklus 2 .

\section{Siklus 1}

Sesuai dengan tahapan dalam penelitian tindakan kelas, maka dalam rangka menjelaskan proses penerapan metode diskulsi kelompok kecil dan media gambar, dapat dijelaskan pada langkah-langkah berikut ini.

\section{Perencanaan}

Penyamaan persepsi tentang: (1) proses penerapan metode diskusi kelompok kecil dan media gambar; (2) melakukan simulasi tentang pembelajaran dengan menggunakan metode diskusi kelompok kecil dan media gambar. Hal ini dilakukan tidak setiap pertemuan perkuliahan, namun hanya dilakukan setiap pertemuan tertentu saja, agar tidak mengganggu proses perkuliahan. Kegiatan pelatihan ini dimulai pukul 13.00 siang setelah para Mahasiswa selesai mengiukuti proses pembelajaran. Dengan demikian kegiatan ini tidak mengganggu sama sekali terhadap kegiatan belajar mengajar Mahasiswa. Media gambar yang didiskusikan dalam kegiatan penyamaan persepsi tersebut adalah gambar tentang dialog antar Mahasiswa dalam kegiatan menyapa, mengucapkan selamat, ucapan terimah kasih, dan permintaan maaf.

Setelah seluruh prosedur penelitian disimulasikan kegiatan selanjutnya adalah menganalisis materi yang terkait dengan membuat kalimat sapaan, ucapan selamat, ucapan terima kasih, dan permintaan maaf, yang ada pada silabus. Setelah itu dilanjutkan dengan menyusum silabus lengkap dengan penerapan metode, media dan asesmennya serta beberapa lembar observasi dan daftar pertanyaan yang dibutuhkan.

Pada siklus 1 ini kegiatan pembelajaran dilakukan dalam dua kali pertemuan (4 x 45 menit). perkuliahan dilakukan pada setiap hari Senin (tanggal 20 dan 27 Oktober 2018) mulai pukul 07.00 sampai pukul 08.10 WIB.

\section{Pelaksanaan}

Pada tahap tahap ini, peneliti mengajar materi sesuai rencana, yaitu tentang penyusunan kalimat sapaan, ucapan selamat, ucapan terima kasih, dan permintaan maaf, 
yang telah dipersiapkan. Selama proses pembelajaran, peneliti telah menerapkan metode diskusi kelompok kecil dan menggunakan media gambar sesuai dengan yang telah dipersiapkan senbelumnya. Di samping mengajar, sekaligus peneliti juga melakukan kegiatan asesmen, baik yang berkaitan dengan aspek proses penerapan metode maupun aspek media yang gambar yang dipakai oleh peneliti.

Langkah-langkah dalam proses pembelajaran pertama-tama peneliti menjelaskan ruang lingkup materi, dan tujuan pembelajaran atau kompetensi yang ingin dicapai oleh para Mahasiswa. Kemudian guru membagi Mahasiswa dalam enam kelompok sesuai nomer absen. Setelah kelompok terbentuk, masingmasing kelompok diberi tugas untuk mendiskusikan gambar. Tiap-tiap kelompok menerima empat macam gambar yang berbeda sama yakni gambar tetang dialog yang berkaitan dengan sapaan, ucapan selamat, ucapan terima kasih, dan permintaan maaf. Masing-masing kelompok harus mendiskripsikan ke empat gambar tersebut, lalu lanjutkan dengan berlatih membuat kalimat.

Langkah selanjutnya peneliti meminta kepada tiap-tiap kelompok untuk mendeskripsikan gambar maupun menjawab beberapa pertanyaan, yang dianggap penting oleh peneliti. Sebab dimungkinkan Mahasiswa kurang cermat dalam mendiskripsikan suatu gambar, padahal objek-objek tersebut sangat penting untuk mendukung tercapainya kompetensi yang telah ditetapkan oleh peneliti.

Pada akhir diskusi masingmasing kelompok diminta untuk melaporkan hasil diskusi, juga dilakukan tes formatif. Kegiatan akhir diskusi sekaligus merupakan kegiatan akhir pembelajaran, Pada kegiatan akhir ini guru juga memberikan tes formatif, yaitu dengan meminta anak untuk membuat berbagai kalimat,

\section{Observasi}

Kegiatan observasi dilakukan pada saat proses pembelajaran berlangsung. Observasi utamanya dilakukan oleh peneliti dan dibantu oleh rekan peneliti). Observasi lebih difokuskan pada proses 
berlangsungnya kegiatan pembelajaran, utamanya yang berkaitan dengan keterampilan guru dalam mengajarkan proses pembuatan kalimat dengan menggunakan metode diskusi kelompok kecil dan penggunaan media gambar, maupun aktivitas Mahasiswa dalam kegiatan berdiskusi. Keterampilan dosen sebagai peneliti yang diamati tidak hanya difokuskan pada keterampilan dalam membimbing diskusi, tetapi juga kemampuan dalam memberikan penjelasan tambahan untuk memperjelas suatu konsep baik yang berkaitan dengan struktur kalimat maupun jenis-jenis kalimat.

Selain menggunakan lembar observasi, peneliti juga menggunakan catatan bebas untuk merekam segala peristiwa yang terjadi saat berlangsungnya kegiatan pembelajaran. Catatan bebas utamanya digunakan untuk mencatat segala aktivitas yang tidak terekam pada saat obeservasi. Di samping itu, peneliti juga melakukan wawancara kepada sekelompok Mahasiswa untuk mengetahui apakah mereka mengalami kesulitan atau tidak selama berlatih membuat kalimat yang nantinya akan diajarkan pada muridnya kelak.

\section{Refleksi}

Pada tahap refleksi, peneliti dan dibantu oleh tim untuk melakukan analisis, interpretasi dan evaluasi terhadap kegiatan-kegiatan yang telah dilakukan sebelumnya, seperti hasil kegiatan observasi, hasil dari catatan bebas, hasil wawancara.. Semua kegiatan ini utamanya adalah untuk mengetahui tingkat keberhasilan peneliti dalam menerapkan metode diskusi kelompok kecil dan media gambar. Beberapa kegiatan yang dianalisis, diinterpretasi dan dievaluasi meliputi: a) aktivitas guru dalam melakukan proses pembelajaran; b) tanggapan Mahasiswa tentang pelaksanaan pembelajaran dengan menggunakan metode diskusi kelompok kecil dan media gambar. Pada saat implementasi awal, suasana kelas sedikit agak kaku. Mahasiswa masih merasa asing terhadap cara belajar yang dianggap lain dari biasanya. Ketidak kondusifan kelas ini disebabkan oleh cara mengajar yang lain dari 
biasanya. Kalau dulu lebih banyak menjelaskan dan mendominasi kelas, namun saat ini guru lebih banyak memberikan kesempatan kepada Mahasiswa melalui model tanya jawab.

Selama proses observasi, semua yang terlibat dalam kegiatan masih belum fokus dalam merekam semua kegiatan pembelajaran. Hal ini, diakibatkan karena banyaknya lembar observasi yang harus dipakai oleh peneliti baik yang bersifat individu maupun kelompok. Juga karena suasana Mahasiswa yang sedikit agak gaduh, karena ingin berebut dalam menjawab pertanyaan.

Hasil analisis catatan bebas menunjukkan bahwa beberapa permasalahan seperti dipaparkan di atas, di antaranya terjadi karena tim peneliti agak gugup dalam menanggapi jawaban dan pertanyaan Mahasiswa. Hal ini barangkali disebabkan pula oleh kehadiran anggota tim peneliti lainnya (utamnya dari pihak dosen yang ikut masuk ke dalam kelas). Kondisi tersebut bahkan menjadi agak kurang alamiah karena beberapa anak dari kelas lain banyak yang menonton kegiatan pembelajaran tersebut.

Akhir kegiatan pada siklus pertama ini dapat ditengerai bahwa pembelajaran tentang menulis kalimat sapaan, ucapan selamat, ucapan terima kasih, dan permintaan maaf yang dilaksanakan dengan pendiskusian gambar dan diskusi kelompok kecil sudah dapat dikatakan cukup efektif. Hal ini ditandai dengan beberapa keterangan yang telah berhasil dihimpun melalui beberapa teknik. Yang mana beberapa informasi tersebut telah dicrosscek melalui triangulation approach (memanfaatkan beberapa pendekatan dalam proses pengumpulan data). Namun demikian, masih ada beberapa hal kecil yang masih perlu ditingkatkan pelaskanaannya, misalnya masih muncul kekakuan di saat-saat awal pembelajaran, guru masih sulit dalam memanage kelas, waktu pembelajaran, dan dalam melakukan observasi, juga interaksi dalam kelompok juga masih bekum berjalan dengan baik

Atas dasar kondisi tersebut, maka masih diperlukan perbaikan 
pada siklus berikutnya. Beberapa hal penting yang masih perlu ditingkatkan pelaksanaannya adalah: cara guru dalam menstimulus Mahasiswa; cara memanage kelas; cara dalam mengobservasi, dancara dalam pembntukan kelompok diskusi.

\section{Siklus 2}

Pada siklus 2 sebenarnya merupakan suatu kegiatan pembelajaran yang dilakukan untuk memperbaiki proses pembelajaran yang belum dianggap berhasil Siklus 2 ini dilaksanakan pada tanggal 3 November 2018 mulai jam 09.00 hingga 10.15 WIB.

\section{Perencanaan}

Berdasarkan hasil analisis pada kegiatan siklus pertama, maka masih diperlukan beberapa perbaikan, agar hasil yang diharapkan bisa lebih baik. Pada tahap ini semua persiapan dilakukan berdasarkan beberapa kelemahan yang terjadi pada siklus pertama. Untuk itu, ada beberapa perencanaan ulang yang perlu dilakukan, baik berkenaan dengan aktivitas peneliti, Mahasiswa, maupun yang berkenaan dengan media dan sarana pembelajaran lainnya.

Untuk meningkatkan keterampilan dalam menggunakan media dan membimbing diskusi kelompok kecil, peneliti mengadakan diskusi untuk mengidentifikasi kelemahan-kelemahan yang terjadi pada siklus pertama. Selain itu, peneliti juga meminta keterangan pada beberapa Mahasiswa tentang pelaksanaan pembelajaran yang lalu agar pembelajaran berikutnya bisa menjadi lebih baik lagi.

Strategi peneliti dalam membimbing kelompok kecil selama proses pembelajaran akan diarahkan agar supaya Mahasiswa bisa menganalisis gambar secara lebih detail lagi. Misalnya Mahasiswa tidak hanya menceriterakan objek gambar yang pokok saja, tetapi mereka dirangsang untuk mampu menjelaskan secara lebih komprehensif tetang semua objek yang bisa dijelaskan dari gambar yang sedang mereka diskusikan. Untuk meningkatkan partisipasi Mahasiswa pada pelaksanaan siklus kedua ini direncanakan bagi kelompok Mahasiswa atau individu 
yang mampu memberikan penjelasan gambar secara lebih lengkap diberi hadiah biskuit atau permen. Guru dalam kegiatan ini harus lebih jeli dalam mendengarkan penjelasan Mahasiswa. Apakah semua objek telah dibahas dengan lengkap atau belum. Bila belum maka guru harus terus berupaya agar para Mahasiswa mau berfikir lebih komprehensif lagi sehingga seluruh objek gambar dapat dijelaskan oleh Mahasiswa.

Rencana observasi yang akan dilakukan oleh peneliti tidak selalu dilakukan dengan menunggu dari dekat kepada tiap-tiap kelompok, namun akan dipantau dari depan kelas. Cara ini dimaksudkan agar supaya para Mahasiswa tidak merasa diawasi dan memberikan kebebasan mereka untuk bisa lebih kreatif lagi mengeksplore suatu objek gambar dan berlatih dalam membuat kalimat (sapaan, ucapan selamat, ucapan terima kasih, dan permintaan maaf)..

Aktivitas yang direncanakan pada siklus 2 ini termasuk proses pembentukan kelompok. Pada siklus 2 kelompok dibentuk berdasarkan tingkat meampuan yang beragam dan juga keterdekatn antar anggota kelompok. Hal ini berbeda dengan siklus 1 dimana proses pembentukan kelompok didasarkan pada nomor presensi.

\section{Pelaksanaan}

Diadakannya perencanaan ulang sesuai dengan beberapa kelemahan yang terjadi pada siklus pertama, maka pelaksanaan pembelajaran pada siklus ke dua ini, lebih difokuskan pada upaya untuk merubah kegiatan sesuai hasil refleksi pada siklus pertama. Kegiatan pelaksanaan pada siklus kedua ini dapat dijelaskan sebagai berikut:

Pertama-tama guru membuka pelajaran sambil mengajukan beberapa pertanyaan sebagai aperseprsi. Setelah itu guru menjelaskan materi yang akan dibahas pada hari itu, termasuk batas-batas materi yang akan dipelajari. Masih dalam kegiatan pembukaan, guru membagi kelas dalam enam kelompok. Pada siklus kedua ini anggota kelompok diperbarui, namun masih tetap mempertimbangkan heterogenetas kelompok. Hal ini dimaksudkan agar suasana kelompok menjadi lebih 
hidup, karena setiap anggota kelompok pasti memiliki pengalaman yang berbeda.

Pada kegiatan inti (kegiatan penyajian), guru membagikan beberapa set gambar tentang percakapan antar Mahasiswa. Yaitu aktivitas yang menggambarkan percakapan antar Mahasiswa dengan menggunakan kalimat sapaan, ucapan terima kasih, ucapan selamat, dan permintan maaf. Dalam kegiatan ini guru mencoba untuk memberi kesempatan agar Mahasiswa mampu menggali informasi yang terdapat pada gambar secara lebih detail dan lebih komprehensif. Dan bagi anggota kelompok yang bisa memberi gambaran secara lebih detail dan mampu mengerjakan tugas dengan baik tetap akan diberi pujian dan semangat.

\section{Observasi}

Pada kegiatan observasi ada beberapa hal yang diamati, yaitu: a) aktivitas guru selama mengajar dengan menerapkan metode diskusi dan gambar dalam beberapa kelompok Mahasiswa, b) aktivitas Mahasiswa selama mengikuti proses pembelajaran, seperti kegiatan
Mahasiswa selama mendiskusikan gambar dan bagaimana proses mereka dalam menyimpulkan objek gambar maupun mencatat kecenderungan Mahasiswa dalam membuat kalimat sesuai materi yang ada pada objek gambar.

Observasi juga dilakukan dengan membuat catatan bebas untuk mencatat beberapa peristiwa yang tidak terekam dalam kegiatan observasi yang telah dipersiapkan. Kegiatan observasi dilakukan tiadak secara langsung. Kegiatan tersebut dilakukan pada saat proses pembelajaran berlangsung (pada tahap pelaksanaan).

\section{Refleksi}

Pada tahap refleksi, peneliti berupaya untuk menganalisis, menginterpretasi dan mengevaluasi kegiatan-kegiatan sebelumnya seperti halnya pada siklus pertama. Beberapa hal yang dianalisis dan dievaluasi adalah hasil kegiatan observasi, hasil dari catatan bebas, hasil wawancara, dan hasil tes. Semua kegiatan ini dilakukan utamnya untuk mengetahui tingkat keberhasilan dan pencapaian tindakan pada siklus ke dua. 
Fokus dari kegiatan refleksi meliputi: a) kegiatan guru dalam melakukan proses pembelajaran; b) efektifitas proses pembelajaran; c) aktivitas belajar Mahasiswa, d) serta achievement dan persepsi Mahasiswa. Di samping itu, juga mendiskusikan efektivitas tim peneliti dalam melakukan kegiatan observasi itu sendiri.

Aktivitas mengajar pada siklus 2 sudah semakin bagus dan mantap, suasana kelas sudah terbangun dengan baik. Mahasiswa sudah mulai bisa konsentrasi dan bisa menyelesaikan tugas sesuai penjelasan yang ada. Artinya Mahasiswa secara otentik telah mampu menjelaskan berbagai objek yang ada pada gambar. Selain itu, peneliti juga sudah semakin terampil mengajar dengan menggnakan metode diskusi danmenerapkan media gambar yang dilakukan dalam berbagai kelompok kecil.

Efektifitas pembelajaran sudah mulai nampak. Hal ini ditandai dengan semakin cepat dan komprehensifnya anak dalam mendiskripsikan suatu gambar. Bahkan untuk beberapa kasus gambar, anak mampu memberikan penjelasan berdasarkan pengalaman mereka yang diperoleh melalui kegiatan informal.

Aktivitas belajar Mahasiswa sudah semakin baik tidak kaku seperti suasana yang terjadi pada siklus pertama. Anak-anak sudah mampu dan mau mengekplore objek gambar sedetail mungkin, dan bahkan mau menanyakan beberapa hal yang dianggap membingungkan dalam membuat kalimat, seperti contoh yang ada pada objek gambar Ini semua mengindikasikan bahwa partisipasi anak mulai berkembang dan suasana menjadi semakin kondusif, proses diskusi kelompok kecil menjadi semakin hidup, mereka saling mengisi dan membantu teman yang belum mengerti. Kondisinya menjadi semakin lebih baik lagi setelah poeneliti memberikan informasi bahwa bagi kelompok Mahasiswa yang bisa menjelaskan gambar dengan lengkap akan diberi hadiah (berupa biskuit dan permen).

Beberapa pertanyaan yang dilontarkan pada tiga Mahasiswa setelah selesai proses pembelajaran juga menunjukkan hal yang 
menggembirakan. Rata-rata persepsi mereka terhadap model pembelajaran yang dilakukan oleh guru adalah positif. Mereka merasa enjoy dan lebih mudah dalam menerima pelajaran, mereka juga bisa mendiskusikannya dengan teman kelompoknya.

Observasi yang dilakukan oleh tim dosen ternyata sangat tepat. Yaitu dengan tidak melibatkan diri dalam proses diskusi ternyata lebih memberikan keleluasaan anak dalam mengekspkore suatu gambar. Padahal sebelumnya mereka agak malu-malu dan bahkan takut salah dalam menjawab atau menjelaskan suatu gambar.

Berdasarkan beberapa realita di atas, mengindikasikan bahwa kegiatan pembelajaran dengan mengimplementasikan metode dan media yang belum biasa dipakai oleh peneliti dapat dikatakan efektif. Hal tersebut ditandai dengan: a) guru sudah terampil dalam melaksanakan proses pembelajaran dengan baik b) Mahasiswa merasa senang dan termotivasi untuk mempelajari materi yang diberikan oleh guru; c) adanya peningkatan pemahaman dan daya kritis Mahasiswa

$\begin{array}{llr}\text { Kemampuan } & \begin{array}{l}\text { Mahasiswa } \\ \text { Membuat }\end{array} & \begin{array}{r}\text { kalam } \\ \text { Ketelahat }\end{array} \\ \text { Penerapan } & \text { Metode } & \begin{array}{r}\text { Diskusi } \\ \text { Kelompok }\end{array} \\ \text { Kecil dan } & \text { Media } \\ \text { Gambar } & & \end{array}$
Kemampuan Mahasiswa dalam membuat kalimat sapaan, ucapan selamat, ucapan terima kasih, dan permintaan maaf dapat dilihat dari hasil belajar setelah berakhirnya proses pembelajaran. Hasil belajar tersebut diperoleh dari hasil tes formatif yang dilakukan melai siklus 1 hingga siklus 2. Ada empat hal yang dinilai dalam tersebut yaitu pertama anak diminta untuk membuat kalimat sapaan, kalimat untuk mengucapkan selamat dan terima kasih, dan kalimat permintaan maaf. Hasil dari pemahaman Mahasiswa tersebut akan disajikan dalam setiap siklus sebagai berikut.

Siklus 1

Hasil belajar tentang kemampuan Mahasiswa dalam membuat kalimat dapat dilihat pada tabel-tabel di bawah ini. 
Tabel Hasil Belajar Kemampuan Membuat Kalimat dilihat dari Beberapa Aspek

\begin{tabular}{|c|l|c|c|c|}
\hline No. & \multicolumn{1}{|c|}{ Aspek yang dinilai } & Prosesntase & Kategori & Keterangan \\
\hline 1 & Struktur Kalimat & 62 & C & Cukup \\
\hline 2 & Jenis kalimat & 65 & C & Cukup \\
\hline 3 & Penggunaan huruf kapital & 68 & C & Cukup \\
\hline 4 & Tanda baca & 60 & C & Cukup \\
\hline 5 & Kosa kata & 61 & C & Cukup \\
\hline
\end{tabular}

Sumber: primer

Hasil belajar di atas menunjukkan bahwa untuk semua aspek yang dinilai belum menunjukkan hasil yang ditargetkan oleh peneliti. Sebab dalam hal ini peneliti mentargetkan bahwa semua elemen yang dinilai masih di bawah nilai 70 .

Sementara hasil belajar setiap Mahasiswa masih juga belum menunjukkan hasil yang menggembirakan. Katena masih banyak Mahasiswa yang mendapat nilai kurang dari yang ditargetkan. Hasil belajar tersebut dapat dilihat pada tabel 4.2 berikut .

Tabel Hasil Belajar tentang Kemampuan Mahasiswa dalam Membuat Kalimat

\begin{tabular}{|c|c|c|c|}
\hline Nilai & Keterangan & $\begin{array}{c}\text { Jumlah } \\
\text { Mahasiswa }\end{array}$ & Prosentase \\
\hline $\mathrm{P} \geq 90 \%$ & Sangat baik & 0 & 0 \\
\hline $80 \% \leq \mathrm{p} \leq 90 \%$ & Baik & 1 & 3,22 \\
\hline $65 \% \leq \mathrm{p} \leq 80 \%$ & Cukup baik & 6 & 19,35 \\
\hline $55 \% \leq \mathrm{p} \leq 6 \%$ & Kurang baik & 16 & 51,61 \\
\hline $\mathrm{p}<55 \%$ & Tidak baik & 8 & 25,80 \\
\hline Jumlah & & 31 & 100 \\
\hline
\end{tabular}

Sumber: primer

Siklus 2

Hasil belajar tentang kemampuan Mahasiswa dalam membuat kalimat pada siklus 2 dapat dilihat pada tabel-tabel di bawah ini. 
Tabel 4.3 Hasil Belajar Kemampuan Membuat Kalimat dilihat dari Beberapa Aspek

\begin{tabular}{|c|l|c|c|c|}
\hline No. & \multicolumn{1}{|c|}{ Aspek yang dinilai } & Prosesntase & Kategori & Keterangan \\
\hline 1 & Struktur Kalimat & 72 & C & Cukup \\
\hline 2 & Jenis kalimat & 75 & C & Cukup \\
\hline 3 & Penggunaan huruf kapital & 86 & B & Baik \\
\hline 4 & Tanda baca & 83 & B & Baik \\
\hline 5 & Kosa kata & 70 & C & Cukup \\
\hline
\end{tabular}

Sumber: primer

Hasil belajar di atas menunjukkan bahwa untuk semua aspek yang dinilai telah menunjukkan hasil seperti yang ditargetkan oleh peneliti. Sebab dalam hal ini peneliti mentargetkan bahwa semua elemen yang dinilai telah di atas nilai 70 .

Samahalnya dengan secara klasikal, hasil belajar setiap Mahasiswa juga belum menunjukkan hasil yang menggembirakan. Karena telah masih banyak Mahasiswa yang mendapat nilai di atas 70 seperti yang ditargetkan. Hasil belajar tersebut dapat dilihat pada tabel berikut ini.

Tabel 4.4 Hasil Belajar tentang Kemampuan Mahasiswa dalam Membuat Kalimat

\begin{tabular}{|c|c|c|c|}
\hline Nilai & Keterangan & $\begin{array}{c}\text { Jumlah } \\
\text { Mahasiswa }\end{array}$ & Prosentase \\
\hline $\mathrm{p} \geq 90 \%$ & Sangat baik & 1 & 3,23 \\
\hline $80 \% \leq \mathrm{p} \leq 90 \%$ & Baik & 2 & 6,45 \\
\hline $65 \% \leq \mathrm{p} \leq 80 \%$ & Cukup baik & 28 & 90,32 \\
\hline $55 \% \leq \mathrm{p} \leq 65 \%$ & Kurang baik & 0 & 0 \\
\hline $\mathrm{p}<55 \%$ & Tidak baik & 0 & 0 \\
\hline Jumlah & & 31 & 100 \\
\hline
\end{tabular}

Sumber: primer

Selanjutnya tentang perbandingan hasil belajar Mahasiswa dalam membuat kalimat ditinjau dari perolehan skor setiap Mahasiswa dapat dilihat pada tabel berikut. 
Tabel Perbandingan Kemampuan Mahasiswa dalam Membuat Kalimat

\begin{tabular}{|c|c|c|c|c|c|c|c|}
\hline \multirow[b]{2}{*}{ Nilai } & \multirow{2}{*}{$\begin{array}{c}\text { Kategor } \\
\text { i }\end{array}$} & \multicolumn{2}{|c|}{ Pra siklus } & \multicolumn{2}{|c|}{ Siklus 1} & \multicolumn{2}{|c|}{ Siklus 2} \\
\hline & & $\begin{array}{c}\text { Total } \\
\text { Mahasisw } \\
\text { a }\end{array}$ & $\%$ & $\begin{array}{c}\text { Total } \\
\text { Mahasisw } \\
\text { a }\end{array}$ & $\%$ & $\begin{array}{c}\text { Total } \\
\text { Mahasisw } \\
\text { a }\end{array}$ & $\%$ \\
\hline $\begin{array}{c}\mathrm{p} \geq \\
90 \%\end{array}$ & $\begin{array}{c}\text { Sangat } \\
\text { baik }\end{array}$ & 0 & 0 & 0 & 0 & 1 & 3,23 \\
\hline $\begin{array}{c}80 \% \\
\leq \mathrm{p} \\
\leq 90 \%\end{array}$ & Baik & 0 & 0 & 1 & 3,22 & 2 & 6,45 \\
\hline $\begin{array}{c}65 \% \\
\leq \mathrm{p} \\
\leq 80 \%\end{array}$ & $\begin{array}{l}\text { Cukup } \\
\text { baik }\end{array}$ & 6 & $\begin{array}{c}19,3 \\
5\end{array}$ & 6 & $\begin{array}{c}19,3 \\
5\end{array}$ & 28 & $\begin{array}{c}90,3 \\
2\end{array}$ \\
\hline $\begin{array}{c}55 \% \\
\leq \mathrm{p} \\
\leq 65 \%\end{array}$ & $\begin{array}{c}\text { Kurang } \\
\text { baik }\end{array}$ & 20 & $\begin{array}{c}64,5 \\
1\end{array}$ & 16 & $\begin{array}{c}51,6 \\
1\end{array}$ & 0 & 0 \\
\hline $\begin{array}{c}\mathrm{p}< \\
55 \%\end{array}$ & $\begin{array}{l}\text { Tidak } \\
\text { baik }\end{array}$ & 5 & $\begin{array}{c}16,1 \\
2\end{array}$ & 8 & $\begin{array}{c}25,8 \\
0\end{array}$ & 0 & 0 \\
\hline $\begin{array}{c}\text { Jumla } \\
\mathrm{h}\end{array}$ & & 31 & 100 & 31 & 100 & 31 & 100 \\
\hline
\end{tabular}

Sumber: primer

Berdasarkan data yang ada pada tabel 4.5 di atas, bahwa kemampuan Mahasiswa dalam membuat kalimat mengalami peningkatan. Peningkatan terjadi mulai siklus 1 yang lebih baik dibanding dengan pra siklus. Bahkan kenaikan tersebut terjadi pada siklus 2, yakni hampir semua anak mengalami kenaikan. Kenaikan tersebut sudah sesuai dengan target yaitu dengan perolehan nilai di atas 70. Keberhasilan ini dapat dilihat pada tabel 4.6 sebagai berikut.

Tabel 4.6 Perkembangan Hasil Belajr Kemampan Mahasiswa dalam Membuat Kalimat

\begin{tabular}{|c|l|c|c|c|c|c|c|}
\hline \multirow{2}{*}{ Nilai } & \multirow{2}{*}{ Kategori } & \multicolumn{2}{|c|}{ Prasiklus } & \multicolumn{2}{c|}{ Siklus 1 } & \multicolumn{2}{c|}{ Siklus 2 } \\
\cline { 3 - 8 } & $\begin{array}{c}\text { Jumlah } \\
\text { Mahasiswa }\end{array}$ & $\%$ & $\begin{array}{c}\text { Jumlah } \\
\text { Mahasiswa }\end{array}$ & $\%$ & $\begin{array}{c}\text { Jumlah } \\
\text { Mahasiswa }\end{array}$ & $\%$ \\
\hline $\begin{array}{c}65 \% \leq \\
\mathrm{p} \\
\leq 80 \%\end{array}$ & berhasil & 6 & 19,35 & 8 & 25,80 & 31 & 100 \\
\hline$<65 \%$ & $\begin{array}{l}\text { Belum } \\
\text { berhasil }\end{array}$ & 25 & 80,65 & 23 & 74,20 & 0 & 0 \\
\hline \multicolumn{2}{|c|}{ Jumlah } & 31 & 100 & 31 & 100 & 31 & 100 \\
\hline
\end{tabular}

Sumber: primer 


\section{Pembahasan Hasil Penelitian Perbaikan Pembelajaran}

Proses pembelajaran bahasa Indonesia di SD, utamanya tentang pembuatan kalmat sapaan, ucapan selamat, ucapan terima kasih, dan permintaan maaf dengan menggunakan metode diskusi kelompok kecil dan media gambar telah menunjukkan efektivitasnya. Hal ini, dapat dijelaskan dari hasil analisis mulai dari siklus pertama sampai siklus kedua. Peningkatan kemampuan Mahasiswa dalam menyusun kalimat tidak hanya ditunjukkan dari hasil tes tulis, namun juga ditunjukkan dengan semakin meningkatnya proses pemahaman anak terhadap beberapa konsep penyusunan berbagai jenis kalimat seperti di atas. Bahkan setelah didiskusikan dalam beberapa kelompok kecil, mereka mampu menunjukkan perbedaan dari berbagai jenis kalimat. Bukti-bukti kemajuan tersebut diperkuat pula dengan beberapa hasil wawancara antara peneliti dengan beberapa Mahasiswa, maupun dengan guruguru lainnya (sebagai anggota tim).
Hampir semua Mahasiswa menyatakan bahwa pembelajaran tentang penyusunan kalimat dengan memanfaatkan media gambar dan metode diskusi dapat meningkatkan kegairahan belajar dan prestasi Mahasiswa.

Mendasarkan pada beberapa temuan di atas, maka kegiatan penelitian dapat dikatakan telah mampu menjawab permasalahan penelitian. Temuan penelitian ini membuktikan bahwa pemahaman anak dalam membuat kalimat sapaan, ucapan selamat, ucapan terima kasih, dan permintaan maaf aktivitas dapat ditingkatkan melalui penggunaan metode diskusi kelompok kecil dan media gambar.

Akhirnya kegiatan penelitian ini telah mampu memberikan suatu kejelasan bahwa melalui penerapan metode diskusi kelompok kecil dan media gambar dapat membantu Mahasiswa dalam meningkatkan pemahaman tentang penyusunan kalimat, utamanya kalimat sapaan, ucapan selamat, ucapan terima kasih, dan permintaan maaf. Hal ini sesuai yang dinyatakan oleh Robertson 
(1996) bahwa pendikusian suatu gambar dapat memperkuat image seseorang tentang suatu peristiwa.

Hal yang sama juga dikatakan oleh Barba (1998) bahwa fenomena tertentu yang divisualisasikan secara prosedural dapat meningkatkan minat belajar, motivasi, rasa keingintahuan Mahasiswa, dan meningkatkan konsentrasi/perhatian Mahasiswa kepada proses pembelajaran. Pembelajaran tentang penyusunan/ pengembangan kalimat dengan menggunakan metode diskusi kelompok kecil dan media gambar. Akhirnya metode dan media yang diterapkan oleh guru dapat membantu para Mahasiswa dalam membangun pengetahuaannya sendiri, untuk digunakan dalam menyusun berbagai jenis kalimat .

Berdasarkan kajian ini jelaslah bahwa hipotesis penelitian telah mampu menjawab permasalahan penelitian. Juga telah mampu memenuhi tujuan yang diharapkan yakni ditunjukkan oleh meningkatnya efektivitas proses pembelajaran bahasa Indonesia melalui pemanfaatan metode diskusi kelompok kecil dan media gambar

kepada para Mahasiswa Prodi PG PAUD IKIP PGRI JEMBER Jember.

\section{SIMPULAN DAN SARAN TINDAK LANJUT}

\section{A. Simpulan}

Berdasarkan hasil temuan penelitian di kelas, maka dapat disimpulkan bahwa pembelajaran tentang penyusunan kalimat sapaan, ucapan terima kasih, ucapan selamat, dan permintaan maaf menjadi lebih mudah dipahami dan ditindaklanjuti oleh para Mahasiswa melalui kegiatan pendiskusian gambar dalam kelompok kecil. Peningkatan prestasi tidak hanya ditunjukkan dengan meningkatnya kemampuan Mahasiswa dalam menyusun kalimat, tetapi juga ditandai dengan meningkatnya antusiame Mahasiswa dalam mengikuti proses pembelajaran bahasa Indonesia di kelas.

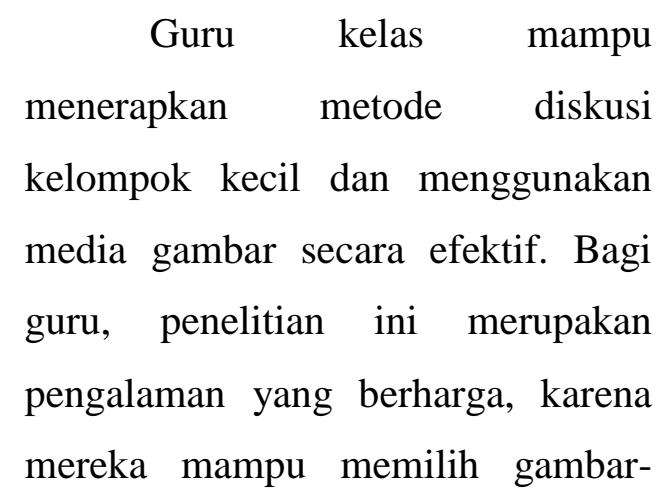


gambar yang mendidik dan mampu mengimplementasikannya dalam proses pembelajaran dalam bentuk diskusi kelompo kecil. Baik secara kuantitatif dan kualitatif, kualitas pembelajaran yang dilakukan oleh guru juga meningkat.

\section{Saran Tindak Lanjut}

Agar implementasi pembelajaran pengembangan kalimat utamanya yang membahas tetang kalimat sapaan, ucapan selamat, ucapan terima kasih, dan permntaan maaf benar-benar efektif, maka: a) guru perlu terus berlatih dan mengembangkan pengetahuan dan keterampilannya dalam mengimplementasikan media gambar dan small group discussion pada pokok-pokok bahasan tertentu yang relevan; b) lembaga sekolah perlu melengkapi fasilitas belajar seperti multimedia sebagai bagian yang urgen sesuai tuntutan Kurikulum 2013 ; c) Mahasiswa perlu terus dibiasakan untuk belajar dengan memanfaatkan berbagai media dan sumber pembelajaran yang menarik.

\section{DAFTAR PUSTAKA}

Barba, H. R. 1995. Science in The Multicultural Classroom. USA:

Allya and Bacon.

Catling, S. 1992. "Children and Geography". In Mild (Ed). Geography Work in Primary and Middle SchoolsSheffield: Geographic Association

DEPDIKNAS. 2013. Buku Paket

Kelas 4 (Pedoman Guru).

Jakarta: Diknas

Kasbolah, K. 1998. Penelitian

Tindakan Kelas (PTK). Jakarta:

Depdikbud Dirjen Dikti Proyek

PGSD IBRD : LOAN - IND

1998/1999.

Law, T. M. 1994. "Primary

Children's Ideasabout

Economically Developing

Countries: A Conparative

Studies of Year 6 Children's

Ideas about Banglades and

Kenya' Unpublished MA

Dissertation. London Instritute of Education of The University of London.

Purnomo, B. H. 1999. Analisis

Keterampilan Anak SD dalam 
Membuat Peta. Majalah

Argopuro Universitas Jember.

Jember: BPUJ

Robertson, M. 1996.'Children's

Understanding of Pattern and

Relationships in Visual
Stimuli’ In: Schee, JVD. Et al

(Eds) Innovation in

Geographical Education,

Amsterdam: Internatioonal

Geographical Union. 